\title{
Impact of Web Based Learning on EFL: Using On-line Discussion Forum (ODF) to Enhance Students' Writing Skill
}

\author{
Akmal \\ English Department, Faculty of Education and Art, University PGRI Semarang, Indonesia
}

Copyright $\bigcirc 2017$ by authors, all rights reserved. Authors agree that this article remains permanently open access under the terms of the Creative Commons Attribution License 4.0 International License

\begin{abstract}
Web based learning is considered as a breakthrough in the teaching of writing skill to the pre-service teachers at University of PGRI Semarang, Indonesia. The students should write argumentative, persuasive, and descriptive essays. This research offers significant contribution in term of the impact of web based learning on writing skill of English as Foreign Language (EFL) learners. There were 156 students who joined ODF but only 63 students $(40 \%)$ were eligible. The objectives were to find its effectiveness for improving students' writing skills. Content, organization, vocabulary, syntax, mechanics, and styles of students' writing were assessed by Brown's writing rubric. Interview was conducted to find out the area of students' difficulties. The results show improvements of means score from 76.47 increased into 80.68 during post-test. The forum has significant influence on improving writing skill (t-test $2.170>\mathrm{t}$-table 1.999). $\mathrm{p}<0.05, \mathrm{df}=62$ as the students submit six to nine postings. It indicates that the students need more practices of writing. Among six writing components, syntax received the most improvement though few students still have problems with conjunctions, passive voice, and conditional clauses.
\end{abstract}

Keywords On-line Discussion Forum, Writing Skill, Pre-service English Teacher

\section{Introduction}

The need to prepare professional skills of pre-service language teachers is a must as they are challenged by different situation at different times, teaching tools, and school levels. The teachers who were trained by using the floppy-disk computer in the 1990s would have different capabilities with those who were given touch-screen and wireless computers. Computer technology has created generation gap between the teachers of the 1900s and the students of the 2000s. Richards and Farrell [1] stated that the pressure for teachers to update their knowledge in areas of curriculum, second language acquisition research, composition theory and practice, technology, or assessment is said to be intense.

Pre-service English students at University of PGRI are without exception. They should be able to merge the technological and pedagogical knowledge for improving their language skills-listening, speaking, reading, and writing - before teaching in the real classroom.

On-line discussion forum (ODF) is an e-learning platform that allows admin to post certain topics to be discussed in which pre-service students can share and type their ideas, suggestions, solutions or remarks upon the topic. With the existence of the teacher as the admin, the forum can stimulate critical thinking, improve communication skills, foster a sense of community among students, and encourage collaborative problems solving. ODF in this setting provides an ample opportunity for improving writing skill of pre-service students because they have more time to think about the topic being studied and to search more information before writing their own in the forum or even the students are able to view feedbacks made by other students and the admin before writing their own.

Pre-service English students at University of PGRI Semarang Indonesia are also prepared for non-teaching profession either as hotel staff, tour and travel operator, translator, etc. Thus they should take English for the Hotel as compulsory curse. Smooth spoken and written communication with hotel's visitors is urgently needed. They should be able to explain hotel facilities and services, give suggestions and recommendation to the hotel's guests, and promote the hotel in the printed media.

Writing skill is not spontaneous skill or acquired easily but it needs complex procedure and involves cognitive processes [2], so the pre-service English students should do more practice over considerable period of time. Therefore, practice writing in the ODF is attached to the course syllabus and the 
investigation of its effectiveness in teaching writing should be conducted for pedagogical purposes.

\section{Research Methodology}

The objectives were to find out the ODF influences on students' writing skill and the students' area of writing problem. There were 156 respondents who joined ODF but only 63 were eligible (more than four postings in an essay format of 300 words). The data were gathered throughout written text in the ODF and interview. Brown's writing rubric was applied to assess content, organization, vocabulary, syntax, mechanics, and styles of students' writing. Statistical analysis was performed to students' writing.

\subsection{Demography of the Subjects}

The subjects in this research were pre-service English students at University of PGRI Semarang, Indonesia who took English for the Hotel course and they were at the 5th semester in the academic year of 2016. They had learned
English for six years in junior and senior high schools and passed basic and intermediate writing (writing 1 and writing 2) with minimum score of 65 (C). There were three English for Hotel classes with total 156 students. All of them were required to participate in the ODF as an integrated part of class-room activities. The subjects write their comments and responds in the form of essay (minimum 300 words) of four problems posted by the admin. The discussion questions were taken from the issues that arose in the classroom session and from the hotel case study. Based on the intensity of the written communication, the required essay format, and minimum 300 words requirement, only 63 students $(40 \%)$ were eligible for taking part in the research.

\subsection{Experimental Set Up}

The subjects should join the ODF through the address: $\mathrm{http}: / /$ esp-upgris.freeforum.net. After having authorization from the admin, they can write their reviews or remarks in a formal tone regarding hotel visitors' complaints, food problems, or promoting hotel services and facilities.

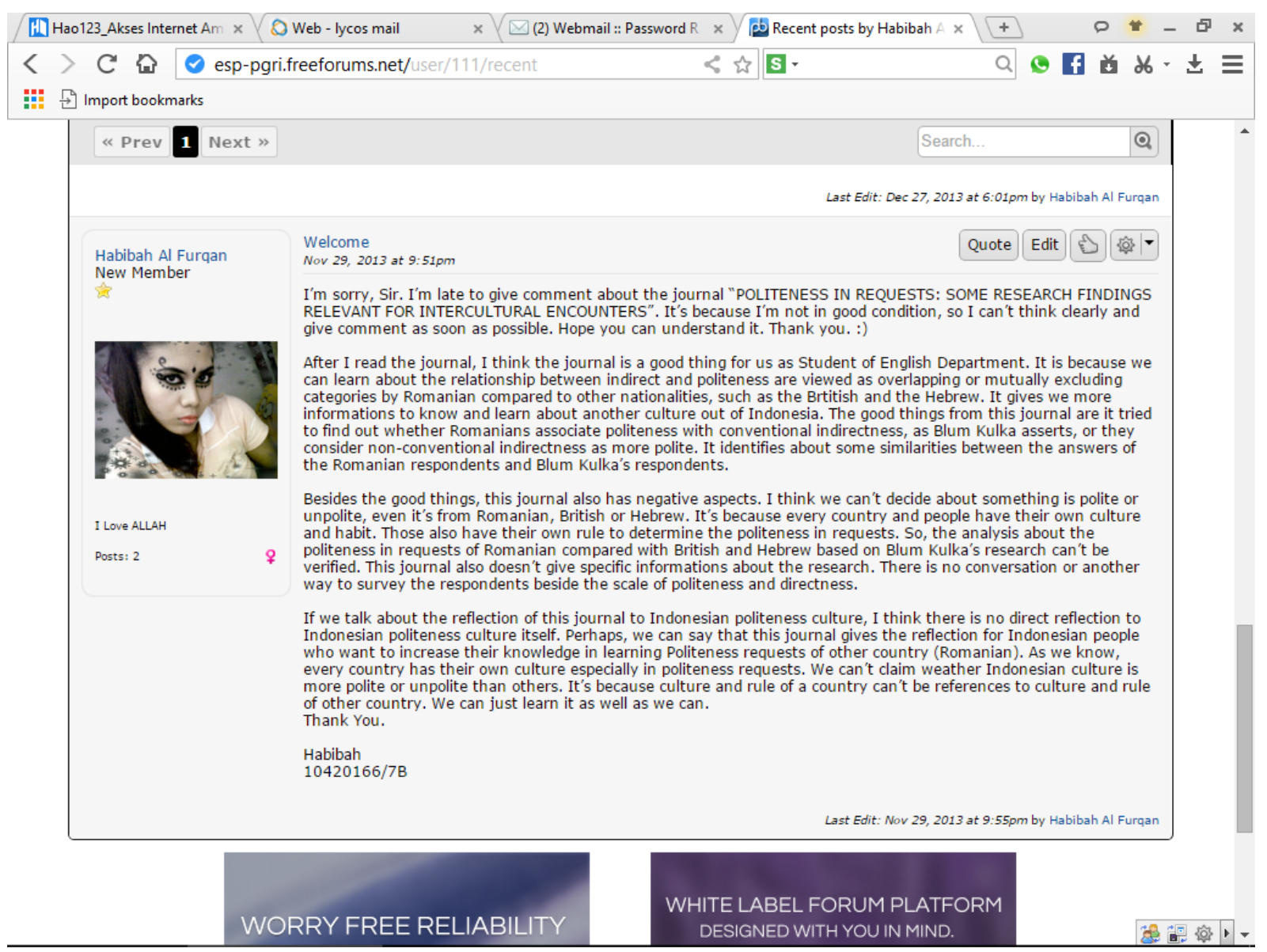

Figure 1. Example of eligible posting 


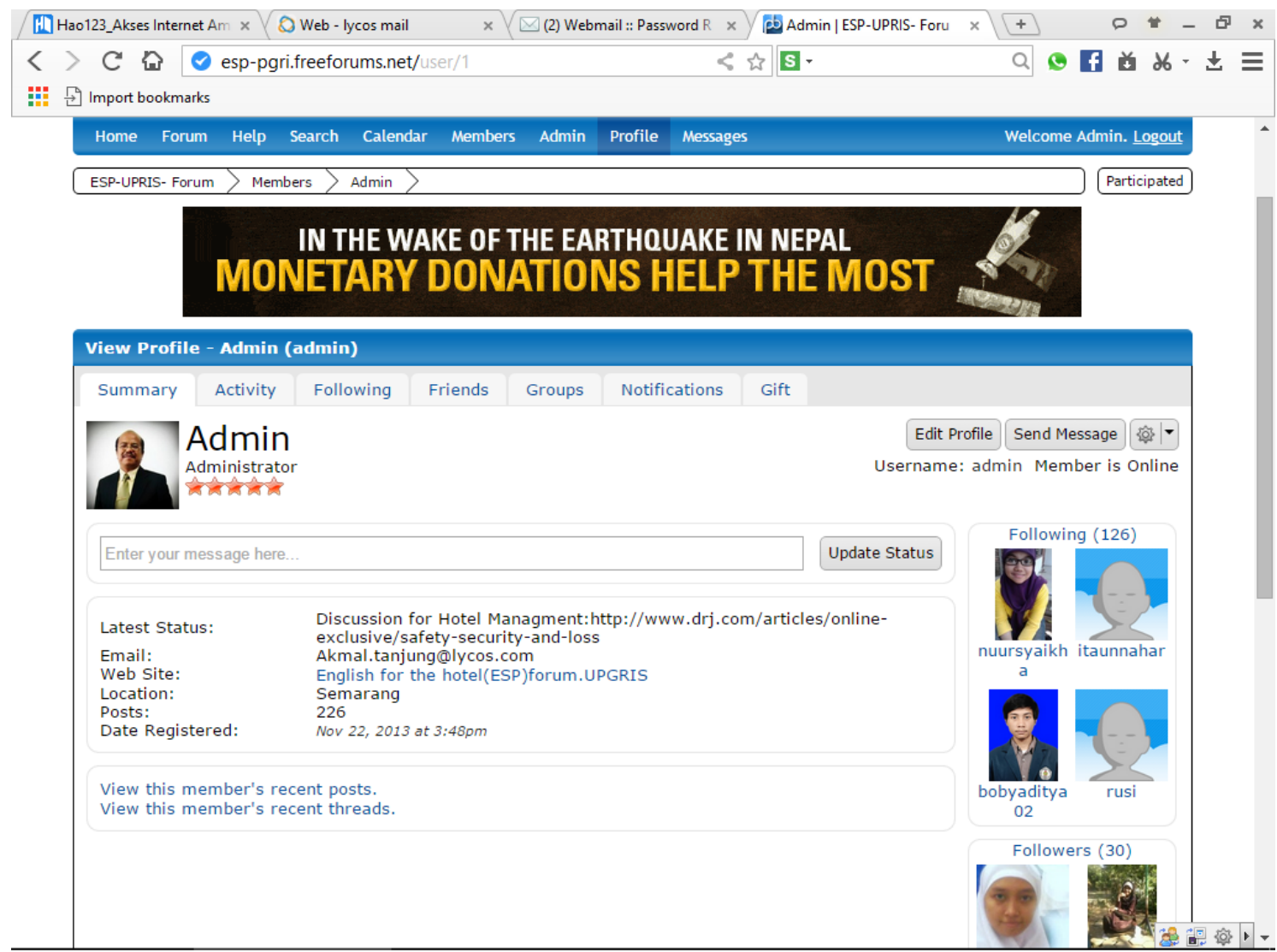

Figure 2. The admin and his 156 students

As the admin, the researcher posted case study and prompt question to be answered in the form of short essay minimum 300 words. The case is related to the topic discussed in the class-room session. In another post, the researcher asked students to evaluate the writing of other students in term of the ideas of the paragraph, sentence structure, coherence, and spelling. Since one of learning outcomes is to enable students to write argumentative, persuasive, or descriptive essay of hotel facilities and services, then "the content, organization, vocabulary, syntax, and mechanic of the students essay are categorized into very poor, fair, good, excellent" [3].

\subsection{Previous Research}

Prior studies showed that online discussion forum (ODF) effectively improved mathematics teacher in sharing, discussing, and reflecting elementary mathematics teaching at elementary school [4]. ODF also improved several aspects of students' skills such as their communication skill, course performance, internet efficacy, collaborative skill, socializing skill, and problem solving $[5,6]$.

Another research revealed that perceived students' satisfaction and perceived quality of the discussion process and outcomes were higher for members of the online group when compared with face-to-face groups [7]. Nevertheless, McMahon [8] found that ODF was not effective because of Teachers' inflexibility and lack of familiarity with the new technology. It means the success of ODF as teaching and learning tool depends on student's personality [9], mechanism that given by the instructor/admin [10], and facilitating discourse [11].

Although there are many advantages for students, the report on Online Discussion Forum's effectiveness for teaching and learning writing skill is still unsatisfactory.

\section{Results and Discussions}

Statistical data on discussion forum show that the students made a total of 525 postings from four threats given by admin during one semester. In terms of timing, $65 \%$ out of 153 students posted their response on the due date (one-two days after admin posting the threat), while $35 \%$ posted after the deadline (on the third or the fourth day).There were 63 students who posted more than four times; 21 students out of 63 posted 6-9 times $(33.3 \%)$. It was also found that 7 students $(11 \%)$ had 12-16 postings. Most responses of the first threat comprised of one paragraph less than 300 words saying thank you for inviting to the forum and informing that the forum was completely new to the students. Though they used simple sentences and non-hotel expressions, they were very glad to have ODF as learning media.

The second responses indicate an improvement of student understanding was influenced by learning feedback given by the admin on the first posting and the responses of other students. Means score of their writing before using ODF was 
76.47 increased into 80.68 during post-test. The results show that the forum has significant influence in improving writing skill (t-test $2.170>\mathrm{t}$-table 1.999).p $<0.05, \mathrm{df}=62$ ). It implies that the admin's/teacher's feedbacks have increased students' participation. Prompt feedbacks given by the admin on the students' writing have helped them learn faster and more effectively as they know immediately what aspects of their writing should be improved. In addition, analyzing peers' writing posted in the forum is also an influential factor of writing improvement. These results confirm the statement mentioned by Ellis et al. [12] that reflective thinking cultivates meaningful interactions in ODFs.

Among six writing components (content, organization, vocabulary, syntax, mechanics, and styles), syntax received the most improvement though few students still have problems with the use of passive voice, conditional clause, and conjunctions (and, or, however, but).From the interview, it is revealed that lack of previous class room explanation and exercises is the explanation to these problems.

From several postings made by a single student, it was found that he/she learns and does self-evaluation on the second, third, and fourth postings. With six to sixteen postings, errors and mistakes can be eliminated. It means after posting their first ideas and looking at their friends' postings, the students then did some improvement and revised it before publishing into the ODF again.

\section{Conclusions and Suggestions}

The present study contributes significant finding to the theory of ODF learning since it improves students' writing skill. The findings show that admin's responds to the students' posting as well as the postings of other students can motivate weak students to rewrite and repost his comments. In other word, from the practical perspective, the present study suggests that ODF should be embedded into the curriculum of writing subject and the teacher or instructor should play an admin role for the smooth communication among students on the ODF format. Since monitoring, evaluating, scoring, and giving prompt feedback to 63 postings in one day before the class session are really challenging for a busy admin, he/she should be well-prepared with certain deadlines of posting responses and feedbacks. It means the teacher or admin should seriously provide an ample time for the success of the ODF activities.

\section{REFERENCES}

[1] Richards, J., \& Farrell, T. Professional development for language teachers. Cambridge University Press New York. 2005

[2] Nunan, D. Second language teaching and learning. Heinle \& Heinle Boston, 1999

[3] Brown, D. H. Principles of language learning \& teaching. (4th ed.). Longman. New York. 2000

[4] Carboni, L.W. I take comfort in the fact that I'm not alone: Building community through online discussion. Paper presented at the Annual Meeting of the American Educational Research Association, San Diego, CA 2004.

[5] Karacapilidis, N., \& Papadias, D. Computer supported argumentation and Collaborative decision making: The HERMES system. Information Systems, 259-277.2001

[6] Blake, C. Potential of text-based internet chats for improving oral fluency in a second language. The Modern Language Journal, 93(2), 227-240.2009

[7] Jonassen, D. and H. Kwon. Communications Patterns in Computer-Mediated vs. Face-to-Face, ETR\&D. 2001

[8] McMahon, Teresa A. From isolation to interaction? Network-based professional development and teacher professional communication. ERIC Document Reproduction Service No. ED408257. 1997

[9] Cheng Cho Kin, Dwayne E. Paré and et al. 2011. Assessing the effectiveness of a voluntary online discussion forum on improving students' course performance. Computers \& Education, Volume 56, Issue 1, Pages 253-261,2011

[10] Rose, R., \& Smith, A. Chapter 9 Online discussions. In C. Cavanaugh \& R. Blomeyer (Eds.), What works in k-12 online learning (pp. 143-160). Washington, D.C. 2007.

[11] Menchaca, M., \& Bekele, T. Learner and instructor identified success factors in distance education. Distance Education, 29(3),

231-252. Available from http://pathfinder.utb.edu:2653/ehost/ pdf?vid=35\&hid=5\&sid=d1946c29-0e58-41 fd-a231-f1682f9 $6 \mathrm{e} 20 \mathrm{c} \% 40$ sessionmgr 11

[12] Ellis, R. A., Goodyear, P., O'Hara, A., \& Prosser, M. The university student experience of face-to-face and online discussions: Coherence, reflection and meaning. ALT-J, 15(1), 8397. 2007 